\title{
PENGEMBANGAN INSTRUMENT PENGUKURAN KUALITAS LAYANAN PERGURUAN TINGGI: SISTEMATIC LITERATURE REVIEW PADA PUBLIKASI INTERNASIONAL
}

\section{DEVELOPMENT OF MEASUREMENT INSTRUMENTS OF SERVICE QUALITY FOR HIGHER EDUCATION INSTITUTION: SISTEMATIC LITERATURE REVIEW IN INTERNATIONAL PUBLISHING}

\author{
Saiful Ghozi ${ }^{1 *}$, Hilmansyah ${ }^{2}$ \\ ${ }^{1,2}$ Politeknik Negeri Balikpapan, Jl Soekarno Hatta Km 08 ,Balikpapan \\ *E-mail: saiful.ghozi@poltekba.ac.id.
}

\begin{abstract}
ABSTRAK
Dengan semakin meningkatnya kesadaran masyarakat akan tuntutan layanan pendidikan tinggi, kualitas layanan pendidikan tinggi juga semakin mendapat perhatian. Jika perguruan tinggi ingin bertahan dalam persaingan antar perguruan tinggi, maka harus memahami dan menyadari persepsi kepuasan pelayanan oleh perguruan tinggi. Penelitian ini merupakan kajian literatur sistematis (systematic literature review) terhadap dimensi kualitas pelayanan perguruan tinggi di publikasi internasional. Kajian literatur ini dilakukan terhadap database penerbit internasional bereputasi (Emerald; Willey; Springer; Francis \& Taylor; Sage publishing) dalam rangka menemukan trend global dalam menentukan dimensi kualitas pelayanan perguruan tinggi sesuai konteksnya. Studi ini bertujuan untuk mengetahui dimensi- dimensi kualitas layanan perguruan tinggi yang sudah dikembangkan dalam tataran global sesuai dengan konteks perguruan tingginya. Dari hasil analisis dihasilkan 11 pengembangan konseptual model pengukuran kualitas layanan perguruan tinggi yang di kemas dalam beberapa akronim. Kesebelas konsep dimensi tersebut paling banyak ditemukan di database Emerald. Mayoritas pengembngan dimensi merupakan hasil evaluasi dan adaptasi penemuan sebelumnya. Penelitian kedepan masih terbuka untuk mengembangkan dimensi konseptual yang otentik sesuai karakteristik perguruan tinggi dan melibatkan perspektif pengguna layanan yang semakin luas.
\end{abstract}

Kata kunci: systematic literature review, kualitas pelayanan, perguruan tinggi, publikasi internasional.

\begin{abstract}
In line with the increasing awareness of the need for higher education services in the community, attention to the issue of the quality of higher education services is now also getting higher. To survive in the high competition, higher education institutions must know and be aware of the perception of service satisfaction of higher education institutions. This research is a systematic literature review on the dimensions of service quality in higher education. This systematic literature review was conducted on reputable databases, i.e. Emerald, Willey, Springer, Francis \& Taylor, Sage publishing, to find global trends in determining service quality dimensions in higher education institutions. This study aims to provide a direction for developing service quality dimensions for higher education institutions following a global perspective. From the results of a systematic literature review analysis, 11 conceptual development models for measuring the service quality of higher education institutions were identified in several acronyms. The conceptual dimensions are most commonly found in Emerald. The future research is still open to develop authentic conceptual dimensions according to the characteristics of universities and involve a broader perspective of service users.
\end{abstract}

Keywords: systematic literature review, service quality dimensions, higher education institution. 


\section{PENDAHULUAN}

Ada banyak model dan pendekatan dalam pengukuran kualitas pelayanan sebuah organisasi yang menghasilkan produk layanan. Pendekatan pengukuran kualitas layanan yang sudah sering digunakan pada banyak literatur adalah model "SERVQUAL" yang dikembangkan oleh Parasuraman, dkk (1988). Pendekatan tersebut paling popular digunakan dalam banyak penelitian [2] meskipun beberapa penelitian mencoba merevisi dan melengkapinya. Pengukuran dalam model tersebut dilakukan melalui analisis gap antara persepsi kinerja dan harapan melalui 22 item kuisioner yang mewakili 5 dimensi kualitas, yakni (1) Tangible; (2) Realibility; (3) Responsiveness; (4) Assurance; (5) Empathy. Pendekatan selanjutnya adalah model "SERPERF" yang dikembangkan oleh Cronin and Taylor (1992). Model ini dalam rangka menjawab kekurangan model "SERVQUAL" dimana pengukuran harapan dianggap tidak tepat dan membingungkan [4]. Sehingga dibuat model yang lebih sederhana dengan langsung mengukur kinerjanya saja. Selain itu ada pendekatan yang dikemukaan oleh Teas (1993), yakni model "Evaluated Performance (EP)". Dimana instrumen EP yang mengukur gap antara persepsi kinerja dan pencapaian ideal disimpulkan lebih baik dibandingkan dengan model SERVQUAL.

Penggunaan skala pengukuran kualitas layanan diatas dipandang beberapa penelitian belum cukup kuat dalam pengukuran kualitas layanan perguruan tinggi, karena skala yang dikembangkan tidak menyasar secara spesifik kepuasan mahasiswa sebagai pengguna layanan utama. Sehingga dalam beberapa penelitian kontemporer pada publikasi internasional, alihalih digunakan skala tersebut diatas, skalaskala baru yang spesifik untuk pegukuran kualitas layanan perguruan tinggi kemudian banyak dikembangkan.

Literatur pengukuran kualitas layanan perguruan tinggi di Indonesia dalam publikasi internasional salahsatunya dilakukan oleh Sumaedi dkk (2012). Dalam mengukur kualitas layanan perguruan tinggi, melalui studi eksplorasi literatur sebelumnya, Ia menentukan dimensi curriculum, facilities, contact personnel, social activities, education counselors, assessment, and instruction medium. Penelitianan lainnya dilakukan oleh Suroto dkk (2017) yang mengadaptasi dimensi SERVQUAL, yaitu physical evidence (tangibles), reliability, responsiveness, assurance, and empathy. Selanjutnya ada penelitian Ardi et al., (2012) yang menggunakan dimensi kualitas layanan berdasarkan prinsip 5C TQM [9]. Pengembangan konseptual dimensi kualitas layanan perguruan tinggi di Indonesia dilakukan oleh Asnawi \& Setyaningsih, (2020) pada perguruan tinggi islam. Ia mengembangkan tujuh dimensi kualitas layanan perguruan tinggi islam, yaitu (1) empati (empathy), (2) nilai- nilai islam (islamic values), (3) perpustakaan (library), (4) relialibilitas (reliability), (5) daya tanggap (responsiveness), (6) kemampuan dan kompetensi (capability and competence) (7) reputasi universitas (reputation university).

Pengembangan konsep kualitas layanan perguruan tinggi dalam rangka menghasilkan dimensi- dimensi pengukuran yang valid dan reliabel telah banyak dipublikasikan di publikasi internasional. Untuk dapat menghasilkan skala pengukuran yang sesuai dengan dinamika diskusi global, maka diperlukan peta literatur yang memberikan informasi yang lengkap dalam rangka komparasi dan bencmarking untuk penelitian selanjutnya. Untuk itu penelitian ini berupaya melakukan analisis systematic literature review tentang pengembangan dimensi konseptual kualitas layanan perguruan tinggi di publikasi Internasional. Pertanyaan penelitian (Research Question/ $R Q$ ) yang diajukan dalam penelitian ini adalah sebagai berikut.

RQ 1: apa saja dimensi konseptual dari kualitas layanan perguruan tinggi yang sudah dikembangkan dari tahun 2005 hingga sekarang, (2021)?

RQ 2: apa nama dimensi konseptual yang sudah dikembangkan dari tahun 2005 hingga sekarang (2021)?

RQ 3: bagaimana proses singkat pengembangan dimensi kualitas layanan perguruan tinggi yang sudah dilakukan?

\section{METODOLOGI}

Penelitian ini mengikuti pendekatan tiga langkah utama dalam systematic literature review dari Klotz, dkk (2019).

Langkah pertama, menentukan database untuk pencarian referensi artikel jurnal yang terbit tantara tahun 2005 sampai dengan sekarang (September 2021). Database yang digunakan dalam proses pencarian dalam penelitian ini adalah Emerald; Willey; Springer; Francis \& Taylor; Sage publishing. 
Keyword pencarian literatur (search string) yang digunakan adalah kombinasi dari beberapa kata: "((new model) OR (new scale) OR (new dimension) OR (new measure*) AND ((quality of service) OR (service quality) OR (service performance) $O R$ (perceived performance)) $A N D$ ((tertiary education) OR (higher education))".

Langkah kedua, penyaringan hasil yang sudah diidentifikasi untuk memisahkan publikasi yang tidak relevan berdasarkan evaluasi judul, abstrak, dan kata kunci. Pencarian literatur pada peneltian ini terfokus pada artikel jurnal yang membahas pengembangan konseptual model baru dalam menentukan dimensi atau faktor kualitas layanan perguruan tinggi yang dikemas dalam sebuah akronim. Dimensi konseptual yang sudah dikembangkan diberi akronim yang mencirikan dimensi- dimensi yang dihasilkan.

Langkah ketiga, melakukan pencarian forward dan backward untuk penulis dan referensi melalui Google scholar.

\section{HASIL DAN PEMBAHASAN}

Dari rangkaian ketiga langkah pada metodologi diatas, ditemukan artikel jurnal sebanyak 11 artikel yang menyajikan hasil pengembangan dimensi kualitas layanan perguruan tinggi sebagaimana terlihat di Tabel 1. Pengembangan dimensi kualitas layanan tersebut tersebar di berbagai konteks pendidikan tinggi di 7 negara yaitu UK, Hungaria, India, Pakistan, Malaysia, Indonesia, Mexico, dan Turki sebagaimana terlihat di Tabel 2.

Tabel 1. Rekapitulasi hasil pencarian dan penyaringan temuan

\begin{tabular}{llcc}
\hline Pencarian & Database & $\begin{array}{l}\text { Hasil } \\
\text { penelusuran }\end{array}$ & Hasil yang relevan \\
\hline Artikel jurnal & Emerald & 45 & 3 \\
\cline { 2 - 4 } & Springer & 36 & 2 \\
\cline { 2 - 4 } & Francis \& Taylor & 35 & 2 \\
\cline { 2 - 4 } & Willey & 12 & 1 \\
\hline Forward/ backward via & Emerald & - & 3 \\
Google scholar. & & 128 & 11 \\
\hline Jumlah & & & \\
\hline
\end{tabular}

Untuk mengetahui deskripsi singkat proses pengembangan masing- masing pengembangan dimensi konseptual, berikut disajikan narasi masing- masing pengembangannya. Distribusi masing- masing pengembangan dimensi berdasarkan seting negara, database dan jurnal tersaji di Tabel 2 . Terminologi asli dari dimensi yang dihasilkan dari penelitian akan tetap ditampilkan untuk memastikan keaslian dan kontrol terhadap bias.

\section{C TQM model of academic excellence [9]}

Total Quality Manajemen (TQM) adalah sebuah manajemen kualitas yang lebih berfokus pada pelanggan dengan cara melibatkan seluruh level tingkatan karyawan dalam mengerjakan peningkatan ataupun perbaikan secara kontinyu. Sakthivel et al. (2005) mengidentifikasi dimensi kualitas kritis TQM dan mengembangkan model keunggulan akademik (academic excellence) yang disebut sebagai 5C TQM model of academic excellence dan membangun hipotesis bahwa 5 dimensi yang ada pada model tersebut, yaitu (1) komitmen pimpinan puncak (commitment of top management), (2) penyampaian kuliah (course delivery), (3) fasilitas kampus (campus facilities), (4) kesopanan (courtesy), (5) umpan balik pelanggan dan perbaikan (customer feedback and improvement), mampu memprediksi kepuasan mahasiswa atas kinerja akademik perguruan tinggi, sebagaimana yag tersaji dalam Gambar 1.

\section{Service product bundle [12]}

Pelayanan terhadap konsumen dinyatakan sebagai produk yang berwujud dan dilihat sebagai sebuah bundel barang [13]. Sehingga Douglas et al. (2006) mengembangkan skala pengukuran kepuasan layanan perguruan tinggi dalam konteks mahasiswa di Fakultas Bisnis dan Hukum Universitas Liverpool John Moores, Inggris, menggunakan konsep service-product bundle (bundel produk layanan) yang terdiri dari 3 elemen, yakni: (1) barang fisik atau barang fasilitas (the physical or facilitating goods), (2) ketersediaan layanan eksplisit (the sensual service provided - the explicit service), dan (3) layanan psikologis (the psychological service the implicit service). 
HEdPERF [14]

Instrumnen HEdPERF (Higher

Education Performance) [14] merupakan skala pengukuran kepuasan layanan yang dikembangkan untuk menjawab keraguan penggunaan SERVQUAL dalam industri spesifik, yaitu institusi perguruan tinggi melalui ppeprpekktif mahasiswa. HEdPERF terdiri dari 13 item yang diadaptasi dari SERVPERF dan 28 item yang dihasilkan dari tinjauan literatur dan berbagai hasil penelitian kualitatif, yaitu diskusi kelompok fokus, uji coba dalam konteks perguruan tinggi di Malaysia, dan validasi oleh ahli. Model tersebut menghasilkan enam dimensi, yaitu (1) aspek nonakademik (nonacademic aspects), (2) aspek akademik (academic aspects), (3) reputasi (reputation), (4) akses (access), (5) isu program (program issues), dan (6) pemahaman (understanding), dalam mengukur kualitas layanan institusi perguruan tinggi. Dimensi pemahaman kemudian dihapus dari HEdPERF versi modifikasi akhir. Model HEdPERF termasuk model yang banyak diterima oleh para peneliti, dan teridentifikasi telah digunakan setidaknya di tujuh negara berbeda (Danilo dkk, 2017)

\section{EduQUAL [16]}

Dalam upaya mengukur kualitas layanan perguruan tinggi teknik, Mahapatra \& Khan, (2007) mengajukan 5 dimensi kualitas layanan yang disebut sebagai EduQUAL (Education Quality). Kelima dimensi tersebut diperoleh melalui analisis faktor dari 43 item indikator dari berbagai referensi sebelumnya yang sesuai dengan konteks Sistem Pendidikan Teknik (Technical Education System/TES) di India, dan melibatkan beberapa stakeholder (mahasiswa, orantua dan staf rekrutmen perguruan tinggi). Kelima dimensi tersebut adalah luaran pembelajaran (learning outcome), daya tanggap (responsiveness), fasilitas fisik (physical facilities), pengembangan kepribadian (personality development), akademik (academics).

\section{PESPERF [17]}

Seperti yang sudah dibahas sebelumnya, penggunaan HEdPERF [14] dirancang untuk menangkap faktor-faktor penentu kualitas layanan di sektor pendidikan tinggi. Namun, menurut Yildiz \& Kara, (2009), HEdPERF dianggap tidak cukup spesifik untuk menangkap karakteristik perguruan tinggi tertentu, misalkan Sekolah Pendidikan Jasmani dan Ilmu Olah Raga (School of Physical Education and Sports Sciences/ PESS) di Turki. Sehingga Ia mengajukan kerangka konseptual baru untuk menghasilkan faktor-faktor penentu kualitas perguruan tinggi yang lebih spesifik sesuai karakter perguruan tinggi. Melalui analisis faktor dari 30 indikator yang diidentifikasi dari berbagai referensi, Yildiz \& Kara, (2009) menghasilkan 3 dimensi baru yang Ia sebut PESPERF (Physical Education and Sports Performance), yakni (1) aspek akademik (academic aspects), (2) empati (empathy), dan (3) akses (access). Model fit dari CFA yang dihasilkan tergambar dalam Gambar 2.

\section{HESQUAL [18]}

Dalam rangka membangun kerangka konseptual dalam pengukuran layanan perguruan tinggi, Viraiyan et al. (2016) mengembangkan 5 dimensi utama kualitas layanan perguruan tinggi yang disebut Higher Educational Service Quality (HESQUAL). Lima dimensi utama tersebut dihasilkan melalui pendekatan mix method mengikuti filosofi penelitian pragmatis Morgan, (2007). Dimana pada tahap pertama, atribut atau indikator diidentifikasi dari tinjauan literatur ekstensif yang dilakukan dan pengumpulan data kualitatif dalam bentuk wawancara, serta FGD dengan mahasiswa dan akademisi. Sedangkan pada tahap kedua, dilakukan metode kuantitatif diawali dengan uji coba instrument dalam skala sampel yang kecil dilanjutkan dengan uji sampel yang lebih besar melalui analisis faktor. Sehingga dihasilkan lima dimensi, yakni: (1) kualitas administrasi (administrative quality), (2) kualitas lingkunan fisik (physical environment quality), (3) kualitas pendidikan utama (core educational quality), (4) kualitas fasilitas pendukung (support facilities quality), dan (5) kualitas transformasi (transformative quality). Konseptual model yang dihasilkan dapat dilihat di Gambar 3. 
Figure 1.

SC TQM makt of

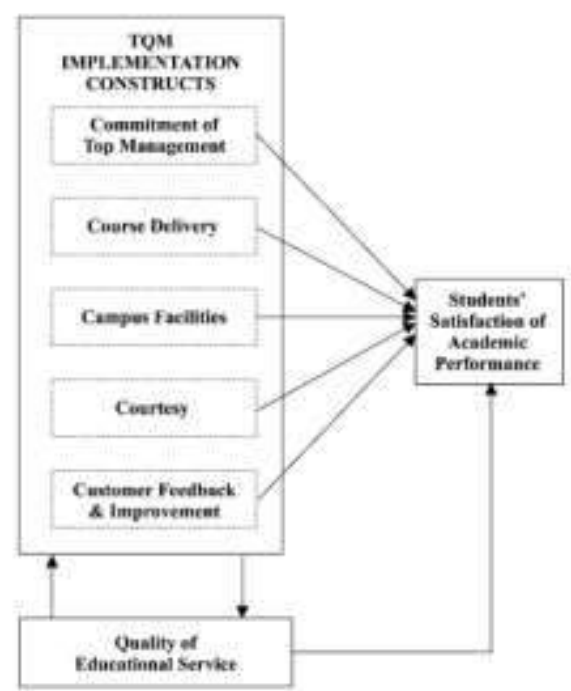

Gambar 1. 5C TQM model of academic excellence [9]
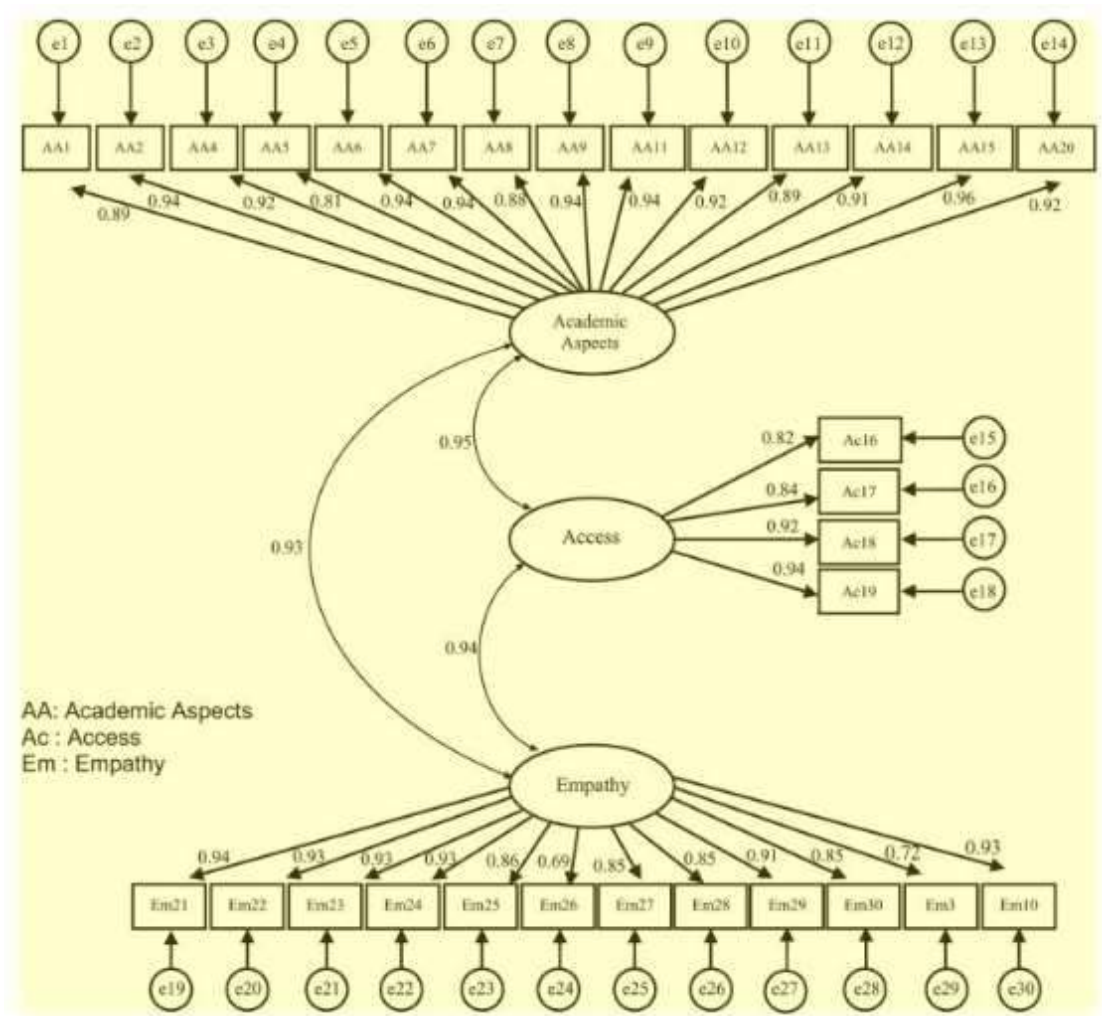

Gambar 2. Hasil Confirmatory Factor Analysis (CFA) pada instrumen PESPERF [17] 


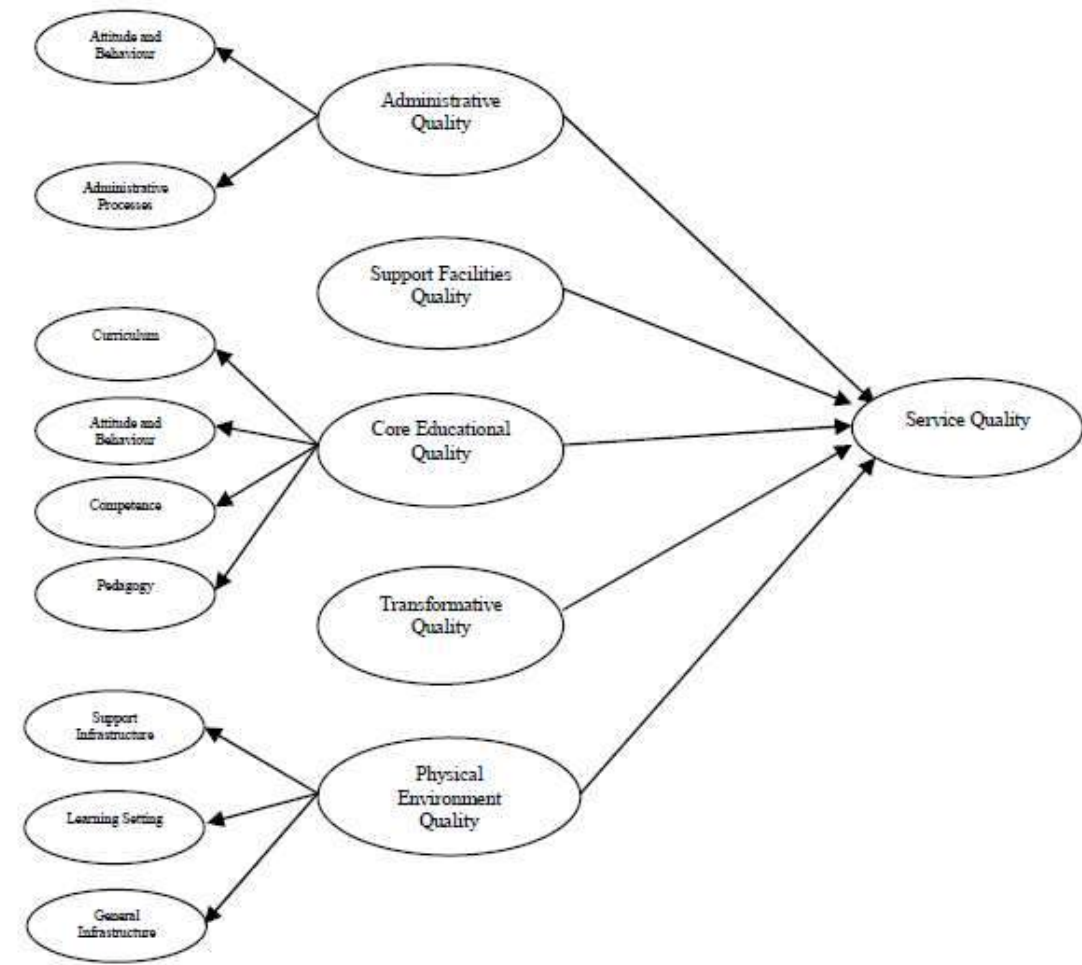

Gambar 3. Konseptual Model Pengukuran Kualitas Layanan Perguruan Tinggi HESQUAL [18]

\section{SQM-HEI [20]}

Dalam rangka perumusan dimensi kualitas layanan perguruan tinggi dalam konteks perguruan tinggi di India, Senthilkumar \& Arulraj, (2011) mengembangkan dimensi baru yang disebut service quality measurement in higher education in India (SQM-HEI). Model tersebut dikembangkan dari hasil evaluasi literatur sebelumnya seperti SERVQUAL, HEdPERF, EduQUAL, dll untuk lebih spesifik membangun konstruk kualitas layanan perguruan tinggi di India melalui perspektif mahasiswa. Dari hasil analisis faktor eksploratori dan eksplanatori pada 30 item butir instrument SQM-HEI akhirnya dihasilkan tiga dimensi utama, yakni (1) metode pembelajaran (teaching methodology), (2) perubahan lingkungan dalam faktor studi (environmental change in study factor), (3) tindakan kedisiplinan (disciplinary actian). Selai itu, ada sub-dimensi yang berperan sebagai mediator terhadap kualitas layanan perguruan tinggi di India, yaitu penempatan (placement).

\section{COURSEQUAL [21]}

Pengembangan instrument pengukuran ini berangkat dari pembagian dua dimensi kualitas layanan, yakni kualitas layanan teknis dan kualitas layanan fungsional [22], dimana kualitas teknis merujuk pada kompetensi apa yang diberikan dari sebuah pembelajaran atau pelatihan dan efisiensinya untuk mencapai kompetensi tersebut. Di sisi lain, kualitas layanan fungsional merujuk pada bagaimana kompetensi dikembangkan, lingkungan yang disediakan, kualitas pengajar, metode dan pengalaman mahasiswa dalam pembelajaran [21]. Kincsesné Vajda dkk (2015) mengembangkan instrument pengukuran kualitas layanan perguruan tinggi yang difokuskan pada kualitas layanan fungsional, yakni kualitas tingkatan kursus (course- level quality) yang diberikan seperti seminar, pelatihan dan perkuliahan. Instrument tersebut dikembangkan melalui analisis faktor butir instrument yang diadaptasi dari SERVQUAL yang diujicobakan pada 181 mahasiswa di Hungaria. Dari hasil analisis faktor tersebut dihasilkan 5 dimensi kualitas layanan fungsional, yaitu (1) kerjasama (cooperation), (2) relialibilitas metode pembejalaran (reliability of teaching method), (3) jaminan dan ketepatan waktu (assurance and punctuality), (4) empati (empathy), dan (5) berwujud (tangibles), yang kemudian disebut sebagai COURSEQUAL.

\section{TEdPERF [23]}

Rodríguez-González \& Segarra, (2016) mengembangkan instrument pengukuran 
kualitas layanan perguruan tingggi melalui beberapa tahapan: (1) eksplorasi aspek layanan kualitas layanan berdasarkan literatur EduQUAL, COURSEQUAL dan HEdPERF, (2) mengidentifikasi 77 item instrument yang siap digunakan, (3) ujicoba (piloting) untuk mendapat umpan balik atau masukan, (4) analisis validitas dan realibilitas untuk kemudian dilakukan rangkaian analisis faktor eksploratori terhadap 50 responden hingga menghasilkan 21 butir instrument, (5) dilakukan analisis faktor konfirmatori terhadap sampel yang lebih besar, sebanyak 204 mahasiswa, di Mexico hingga menghasilkan 18 butir instrument valid. Dari rangkaian tahapan tersebut dihasilkan empat faktor kualitas layanan perguruan tinggi, yaitu (1) aspek akademik (academic aspects), (2) aspek non akademik (nonacademic aspects), (3) reputasi (reputations), dan (4) program yang dijalankan (program issues).

\section{HiEduQual [24]}

Latif, dkk (2017) mengidentifikai 46 butir instrument yang mengukur kualitas layanan perguruan tinggi melalui beberapa tahapan yakni Forum Group Discussion (FGD) yang melibatkan empat stakeholder perguruan tinggi di Pakistan, yaitu mahasiswa, orangtua, pengajar dan pegawai, dilanjutkan validasi ahli, ujicoba, modiifikasi dan perbaikan. Selanjutnya dilakukan analisis faktor baik eksploratori maupun konfirmatori hingga menghasilkan 37 butir instrument yang valid yang terbagi dalam 6 dimensi kualitas layanan, yang disebut sebagai HiEduQual (Higher Education Service Quality), yaitu (1) kualitas guru (teacher quality), (2) layanan administrasi (administrative services), (3) layanan pengetahuan (knowledge services), (4) aktifitas (activities), (5) perbaikan berkelenjutan (continuous improvement), (6) kualitas kepemimpinan (leadership quality).

\section{i-HESQUAL[10]}

Dalam rangka membangun dimensi kualitas layanan yang dirasakan mahasiswa dalam konsteks perguruan tinggi islam di Indonesia, Asnawi \& Setyaningsih, (2020) mengidentifikasi nilai-nilai islam untuk memperkuat validitas konstruk instrument. Butir instrument awal yang dieksplorasi dari beberapa literatur sebelumnya seperti HEdPERF, SQM-HEI, HESQUAL, HiEdQUAL dikombinasikan dengan nila- nilai islam diajukan untuk dilakukan analisis faktor. Dari hasil analissis faktor, dihasilkan 7 dimensi kualitas layanan yang dirasakaan mahasiswa perguruan tinggi islam, yaitu (1) empati (empathy), (2) nilai- nilai islam (islamic values), (3) perpustakaan (library), (4) relialibilitas (reliability), (5) daya tanggap (responsiveness), (6) kemampuan dan kompetensi (capability and competence) (7) reputasi universitas (reputation university). Instrumen yang dihasilkan tersebut dinamakan i-HESQUAL (Islamic Higher Education Service Quality). 
DOI: 10.47002/seminastika.v3i1.287

Tabel 2. Konseptualisasi dimensi pengukuran kualitas layanan perguruan tinggi.

\begin{tabular}{|c|c|c|c|c|c|}
\hline Literatur/ penulis & Negara & Model konseptual & Dimensi kualitas layanan & Database & Jurnal \\
\hline Sakthivel et al. (2005) & India & $\begin{array}{l}\text { 5C TQM model of academic } \\
\text { excellence }\end{array}$ & $\begin{array}{l}\text { (1) komitmen pimpinan puncak (commitment of top } \\
\text { management), (2) penyampaian kuliah (course delivery), } \\
\text { (3) fasilitas kampus (campus facilities), (4) kesopnan } \\
\text { (courtesy), (5) umpan balik pelanggan dan perbaikan } \\
\text { (customer feedback and improvement) }\end{array}$ & Emerald & The TQM Magazine \\
\hline Douglas et al. (2006) & UK & Service product bundle & $\begin{array}{l}\text { (1) barang fisik atau barang fasilitas (the physical or } \\
\text { facilitating goods), (2) ketersediaan layanan eksplisit (the } \\
\text { sensual service provided - the explicit service), dan (3) } \\
\text { layanan psikologis (the psychological service - the } \\
\text { implicit service). }\end{array}$ & Emerald & $\begin{array}{l}\text { Quality Assurance in } \\
\text { Education }\end{array}$ \\
\hline Firdaus, (2006b) & Malaysia & HEdPERF & $\begin{array}{l}\text { 1) aspek nonakademik (non-academic aspects), (2) aspek } \\
\text { akademik (academic aspects), (3) reputasi (reputation), } \\
\text { (4) akses (access), (5) isu program (program issues), }\end{array}$ & Wiley & $\begin{array}{l}\text { International Journal of } \\
\text { Consumer Studies }\end{array}$ \\
\hline Mahapatra \& Khan, (2007) & India & EduQUAL & $\begin{array}{l}\text { (1) luaran pembelajaran (learning outcome), (2) daya } \\
\text { tanggap (responsiveness), (3) fasilitas fisik (physical } \\
\text { facilities), (4) pengembangan kepribadian (personality } \\
\text { development), dan (5) akademik (academics). }\end{array}$ & $\begin{array}{l}\text { Taylor \& } \\
\text { Francis }\end{array}$ & $\begin{array}{l}\text { European Journal of } \\
\text { Engineering Education }\end{array}$ \\
\hline Yildiz \& Kara, (2009) & Turki & The PESPERF & $\begin{array}{l}\text { (1) aspek akademik (academic aspects), (2) empati } \\
\text { (empathy), dan (3) akses (access). }\end{array}$ & Emerald & $\begin{array}{l}\text { Quality Assurance in } \\
\text { Education }\end{array}$ \\
\hline $\begin{array}{l}\text { Senthilkumar \& Arulraj, } \\
\text { (2011) }\end{array}$ & India & SQM-HEI & $\begin{array}{l}\text { (1) metode pembelajaran (teaching methodology), (2) } \\
\text { perubahan lingkungan dalam faktor studi (environmental } \\
\text { change in study factor), (3) tindakan kedisiplinan } \\
\text { (disciplinary actian) }\end{array}$ & Emerald & $\begin{array}{l}\text { Journal of Modelling in } \\
\text { Management }\end{array}$ \\
\hline Kincsesné Vajda et al., (2015) & Hungaria & COURSEQUAL & $\begin{array}{l}\text { (1) kerjasama (cooperation), (2) relialibilitas metode } \\
\text { pembejalaran (reliability of teaching method), ( } 3) \\
\text { jaminan dan ketepatan waktu (assurance and } \\
\text { punctuality), (4) empati (empathy), dan (5) berwujud } \\
\text { (tangibles) }\end{array}$ & Springer & $\begin{array}{l}\text { International Review on } \\
\text { Public and Nonprofit } \\
\text { Marketing }\end{array}$ \\
\hline Viraiyan et al. (2016) & India & HESQUAL & $\begin{array}{l}\text { (1) kualitas administrasi (administrative quality), (2) } \\
\text { kualitas lingkunan fisik (physical environment quality), } \\
\text { (3) kualitas pendidikan utama (core educational quality), } \\
\text { (4) kualitas fasilitas pendukung (support facilities } \\
\text { quality), dan (5) kualitas transformasi (transformative } \\
\text { quality). }\end{array}$ & Emerald & $\begin{array}{l}\text { Quality Assurance in } \\
\text { Education }\end{array}$ \\
\hline
\end{tabular}


DOI: $10.47002 /$ seminastika.v3i1.287

\begin{tabular}{|c|c|c|c|c|c|}
\hline $\begin{array}{l}\text { Rodríguez-González \& } \\
\text { Segarra, (2016) }\end{array}$ & Mexico & TEdPERF & $\begin{array}{l}\text { (1) aspek akademik (academic aspects), (2) aspek non } \\
\text { akademik (non academic aspects), (3) reputasi } \\
\text { (reputations), (4) program yang dijalankan (program } \\
\text { issues). }\end{array}$ & Springer & $\begin{array}{l}\text { International Review on } \\
\text { Public and Nonprofit } \\
\text { Marketing }\end{array}$ \\
\hline Latif et al. (2017) & Pakistan & HiEduQual & $\begin{array}{l}\text { (1) kualitas guru (teacher quality), (2) layanan } \\
\text { administrasi (administrative services), (3) layanan } \\
\text { pengetahuan (knowledge services), (4) aktifitas } \\
\text { (activities), (5) perbaikan berkelenjutan (continuous } \\
\text { improvement), (6) kualitas kepemimpinan (leadership } \\
\text { quality). }\end{array}$ & $\begin{array}{l}\text { Taylor \& } \\
\text { Francis }\end{array}$ & $\begin{array}{l}\text { Total Quality } \\
\text { Management \& Business } \\
\text { Excellence }\end{array}$ \\
\hline $\begin{array}{l}\text { Asnawi \& Setyaningsih } \\
(2020)\end{array}$ & Indonesia & i-HESQUAL & $\begin{array}{l}\text { (1) empati (empathy), (2) nilai- nilai islam (islamic } \\
\text { values), (3) perpustakaan (library), (4) relialibilitas } \\
\text { (reliability), (5) daya tanggap (responsiveness), (6) } \\
\text { kemampuan dan kompetensi (capability and competence) } \\
\text { (7) reputasi universitas (reputation university) }\end{array}$ & Emerald & $\begin{array}{l}\text { Journal of International } \\
\text { Education in Busines }\end{array}$ \\
\hline
\end{tabular}




\section{KESIMPULAN}

Dimensi konseptual kualitas layanan perguruan tinggi yang dikembangkan di berbagai seting perguruan tinggi dapat menjadi petunjuk bagi manajemen institusi perguruan tinggi dalam memberikan perhatian manajerial dalam operasional kerjanya. Sehingga institusi mampu lebih adaptif dengan keinginan pengguna layanan yang diberikan.

Diskusi tentang pendekatan mana yang terbaik untuk mengukur kualitas layanan perguruan tinggi sejauh ini belum pernah terselesaikan. Untuk itu pengembangan konseptual dimensi layanan kualitas perguruan tinggi senantiasa berkembang sesuai dinamika kebutuhan dan tuntutan stakeholder. Penelitian kedepan masih terbuka untuk mengembangkan dimensi konseptual yang otentik sesuai karakteristik perguruan tinggi dan melibatkan perspektif pengguna layanan yang semakin luas.

\section{SARAN}

Penelitian berbasis systematic literature review dapat dilakukan kembali dengan sumber data base yang semakin luas seperti scopus, EBSCO, PPROQUEST, dll dengan pendekatan dan protokol yang lebih baik. Selain itu, ekstraksi dan sintesa temuan yang dihasilkan dapat dilakukan lebih detil dan dalam sehingga memberikan peluang kebaharuan penelitian dimasa yang akan dating.

\section{UCAPAN TERIMA KASIH}

Penelitian ini merupakan bagian dari luaran penelitian yang didanai melalui dana DIPA Poltekba tahun 2021 dengan nomor kontrak: 18/PL32.13/SPK-LT/2021. Ucapan terimakaksih kami ucapkan kepada Pusat Penelitian dan Pengabdian kepada Masyarakat atas dukungan dana yang diberikan. Selain itu juga kami ucapkan kepada semua kolega dan mahasiswa yang ikut memberikan perspektifnya dalam menghasilkan publikasi karya ilmiah ini.

\section{DAFTAR PUSTAKA}

[1] A. Parasuraman, V. A. Zeithaml, and L. L. Berry, "Servqual : A Multiple-Item Scale For Measuring Consumer Perceptions of Service Quality," J. Retail., vol. 64, no. 1, pp. 12-40, 1988.

[2] R. K. Prasad and M. K. Jha, "Quality Measures in Higher Education: A Review and Conceptual Model," J. Res.
Bus. Manag., vol. 1, no. 3, pp. 23-40, 2013.

[3] J. J. Cronin and S. A. Taylor, "Measuring Service Quality: A Reexamination and Extension," $J$. Mark., vol. 56, no. 3, pp. 55-68, Jul. 1992, doi: $10.1177 / 002224299205600304$.

[4] R. J. Angell, T. W. Heffernan, and P. Megicks, "Service quality in postgraduate education," Qual. Assur. $E d u c$. , vol. 16, no. 3, pp. 236-254, 2008, doi:

10.1108/09684880810886259.

[5] R. K. Teas, "Expectations, Performance Evaluation, and Consumers' Perceptions of Quality," J. Mark., vol. 57, no. 4, pp. 18-34, Oct. 1993, doi: 10.1177/002224299305700402.

[6] S. Sumaedi, G. M. Y. Bakti, and N. Metasari, "An empirical study of state university students' perceived service quality," Qual. Assur. Educ., vol. 20, no. 2, pp. 164-183, 2012, doi: $10.1108 / 09684881211219424$.

[7] Suroto, A. Nindiani, and H. H. Purba, "Students' Satisfaction on Academic Services in Higher Education Using Importance-Performance Analysis," ComTech J., vol. 8, no. 1, pp. 37-43, 2017.

[8] R. Ardi, A. Hidayatno, and T. Y. M. Zagloel, "Investigating relationships among quality dimensions in higher education," Qual. Assur. Educ., vol. 20, no. 4, pp. 408-428, 2012, doi: $10.1108 / 09684881211264028$.

[9] P. B. Sakthivel, G. Rajendran, and R. Raju, "TQM implementation and students' satisfaction of academic performance," TQM Mag., vol. 17, no. 6, pp. 573-589, Dec. 2005, doi: 10.1108/09544780510627660.

[10] N. Asnawi and N. D. Setyaningsih, "Perceived service quality in Indonesian Islamic higher education context: A test of Islamic higher education service quality (iHESQUAL) model," J. Int. Educ. Bus., vol. 13, no. 1, pp. 107-130, Jan. 2020, doi: 10.1108/JIEB-11-2019-0054.

[11] S. Klotz, A. Kopper, M. Westner, and S. Strahringer, "Causing factors, outcomes, and governance of shadow IT and business-managed IT: A systematic literature review," Int. J. Inf. 
Syst. Proj. Manag., vol. 7, no. 1, pp. 15-43, 2019, doi: 10.12821/ijispm070102.

[12] J. Douglas, A. Douglas, and B. Barnes, "Measuring student satisfaction at a UK university," Qual. Assur. Educ., vol. 14, no. 3, pp. 251-267, Jan. 2006, doi: 10.1108/09684880610678568.

[13] E. W. Sasser, Management of Service Operations. Allyn And Bacon, Incorporated, 1978.

[14] A. Firdaus, "The development of HEdPERF: a new measuring instrument of service quality for the higher education sector," Int. J. Consum. Stud., vol. 30, no. 6, pp. 569-581, Nov. 2006, doi: $10.1111 / \mathrm{j} .1470$ 6431.2005.00480.x.

[15] Danilo Soares Silva, G. H. S. M. de Moraes, I. K. Makiya, and F. I. G. Cesar, "Measurement of perceived service quality in higher education institutions: A review of HEdPERF scale use," Qual. Assur. Educ., vol. 25, no. 4, pp. 415-439, Jan. 2017, doi: 10.1108/QAE-10-2016-0058.

[16] S. S. Mahapatra and M. S. Khan, "A framework for analysing quality in education settings," Eur. J. Eng. Educ., vol. 32, no. 2, pp. 205-217, May 2007, doi: 10.1080/03043790601118606.

[17] S. M. Yildiz and A. Kara, "The PESPERF scale: An instrument for measuring service quality in the School of Physical Education and Sports Sciences (PESS)," Qual. Assur. Educ., vol. 17, no. 4, pp. 393-415, Jan. 2009, doi: 10.1108/09684880910992359.

[18] T. Viraiyan, T. J. Kamalanabhan, and A. K. Seebaluck, "Measuring service quality in higher education: development of a hierarchical model (HESQUAL)," Qual. Assur. Educ., vol. 24, no. 2, pp. 244-258, Jan. 2016, doi: 10.1108/QAE-06-2014-0028.

[19] D. L. Morgan, "Paradigms Lost and
Pragmatism Regained: Methodological Implications of Combining Qualitative and Quantitative Methods," J. Mix. Methods Res., vol. 1, no. 1, pp. 48-76, Jan. 2007, doi: $10.1177 / 2345678906292462$.

[20] N. Senthilkumar and A. Arulraj, "SQM-HEI - determination of service quality measurement of higher education in India," J. Model. Manag., vol. 6, no. 1, pp. 60-78, Jan. 2011, doi: 10.1108/17465661111112502.

[21] B. Kincsesné Vajda, G. Farkas, and É. Málovics, "Student evaluations of training and lecture courses: development of the COURSEQUAL method," Int. Rev. Public Nonprofit Mark., vol. 12, no. 1, pp. 79-88, 2015, doi: 10.1007/s12208-015-0127-6.

[22] C. Grönroos, "A Service Quality Model and its Marketing Implications," Eur. J. Mark., vol. 18, no. 4, pp. 36-44, Jan. 1984, doi: 10.1108/EUM0000000004784.

[23] F. G. Rodríguez-González and P. Segarra, "Measuring academic service performance for competitive advantage in tertiary education institutions: the development of the TEdPERF scale," Int. Rev. Public Nonprofit Mark., vol. 13, no. 2, pp. 171-183, 2016, doi: 10.1007/s12208-016-0159-6.

[24] K. F. Latif, I. Latif, U. Farooq Sahibzada, and M. Ullah, "In search of quality: measuring Higher Education Service Quality (HiEduQual)," Total Qual. Manag. Bus. Excell., vol. 30, no. 7-8, pp. 768-791, May 2017, doi: 10.1080/14783363.2017.1338133. 